\title{
PERAN DUKUNGAN SOSIAL DAN KECERDASAN EMOSI TERHADAP KESEJAHTERAAN SUBJEKTIF PADA REMAJA AWAL
}

\section{Dhian Riskiana Putri}

\author{
Sekolah Tinggi Ilmu Kesehatan Kusuma Husada \\ dhianrp@gmail.com
}

\begin{abstract}
This study determine the relationship between emotional intelligence, social support, and subjective well-being in early adolescence. The subjects were eighth grade students of SMP Negeri 2 City S, aged 12-15 years, using three scales: subjective well-being scale, emotional intelligence scale, and social support scale. Hypothesis testing using multiple regression analysis with the moderator variable also called Moderated Regression Analysis (MRA). The results showed the value of $R^{2}$ in the regression 3rd model is higher, amounting 0,667 that incorporate the interaction between the emotional intelligence variable and social support variable (as a moderator variable), so the evident that social support variable is right if it was to be a moderator variable, and also it can improve the relationship between emotional intelligence variable and subjective well-being variable.
\end{abstract}

Keywords: Subjective well-being, Emotional intelligence, Social support

\begin{abstract}
Abstrak. Penelitian ini bertujuan mengetahui hubungan antara kecerdasan emosi, dukungan sosial, dan kesejahteraan subjektif pada remaja awal.Subjek penelitian ini adalah siswa kelas VIII SMP Negeri 2 Kota S, berusia 12-15 tahun. Alat ukur menggunakan tiga skala: skala kesejahteraan subjektif, skala kecerdasan emosi, dan skala dukungan sosial. Uji hipotesis menggunakan analisis regresi berganda dengan variabel moderator yang disebut juga sebagai Moderated Regression Analysis (MRA). Hasil penelitian menunjukkan nilai $\mathrm{R}^{2}$ pada model regresi ke-3 lebih tinggi, sebesar 0,667dengan memasukkan interaksi variabel kecerdasan emosi dan variabel dukungan sosial (sebagai variabel moderator), sehingga terbukti variabel dukungan sosial tepat sebagai variabel moderator dan mampu meningkatkan hubungan antara variabel kecerdasan emosi dengan variabel kesejahteraan subjektif.
\end{abstract}

Kata kunci: Kesejahteraan subjektif, Kecerdasan emosi, Dukungan sosial

\section{PENDAHULUAN}

Istilah kesejahteraan subjektif identik dengan kebahagiaan (Diener, 2008), dan terdengar lebih ilmiah (Eid dan Larsen, 2008). Penggunaan istilah kesejahteraan subjektif sebagai sinonim dari kebahagiaan, keduanya digunakan secara bergantian (Diener dan Biswas, 2011).

Kesejahteraan subjektif adalah keseluruhan kepuasan hidup dan kebahagiaan. Kepuasan hidup merupakan ukuran kognitif yang melibatkan penjumlahan penilaian kepuasan hidup dari beberapa domain kehidupan ataupun kepuasan hidup secara umum. Selanjutnya kebahagiaan dianggap sebagai tindakan afektif yang melibatkan emosi (Taylor, Chatters, Hardison, dan Ricky 2001). Dapat dipahami bahwa kebahagiaan merupakan bagian dari kesejahteraan subjektif. Oleh karena itu, dalam penelitian ini, menggunakan istilah kesejahteraan subjektif atau Subjective Well-Being (SWB).

Remaja awal berusia sekitar 12-15 tahun berada pada periode transisi perkembangan fisik, kognitif, sosial, dan emosi, (Santrock, 2007; Mönks, Knoers, dan Haditono, 2004), serta transisi dari sekolah dasar menuju ke sekolah menengah pertama (Schunk dan Meece, 2005; Hurlock, 2004), dihadapkan dengan banyak perubahan dan tuntutan 
baru (Zulkifli, 2006; Ali dan Asrori, 2004; Mönks dkk., 2004), sehingga remaja awal harus mampu menyesuaikan diri dengan baik (Amstrong, 2011). Setiap aspek perkembangan remaja, baik fisik, kognitif, sosial, dan emosi, satu sama lain saling mempengaruhi. Apabila remaja mengalami gangguan pada aspek fisik, maka akan menyebabkan gangguan pada perkembangan aspek lainnya (Yusuf dan Sugandhi, 2012).

Beberapa hasil penelitian menyatakan bahwa mayoritas remaja merasa sejahtera (Berg, George, Edwin, Anja, Basson, Marisa, dan Solomon, 2013; Huebner, Tian, Liu, dan Huang, 2013), dan juga mengalami tingkat kepuasan hidup di atas rata-rata (Basson, 2008). Penelitian yang dilakukan pada remaja Amerika, menemukan bahwa kebanyakan remaja, yaitu sebesar $73 \%$ melihat keseluruhan kehidupan secara positif (Aro dan Soini, 2010). Selain itu, temuan baru-baru ini menyimpulkan bahwa mayoritas remaja mengalami kesejahteraan subjektif tinggi, yaitu berdasarkan hasil penelitian pada remaja Afrika Selatan yang memiliki tingkat rata-rata atas dalam menilai kesejahteraan subjektif (Berg, George, Edwin, Anja, Basson, Marisa, \& Solomon, 2013). Hal ini diperkuat dengan hasil survey awal yang telah dilakukan oleh peneliti pada bulan Oktober 2013 pada 117 siswa kelas VII dan kelas VIII di SMP Negeri 6 Kota Y dan SMP Negeri 23 Kota S, dengan tujuan untuk mengukur kebahagiaan remaja awal, menunjukkan bahwa sebagian besar remaja menyatakan sejahtera, yaitu sebanyak 71 remaja $(60,68 \%)$.

Penelitian kesejahteraan subjektif remaja dilakukan pada siswa kelas VIII di SMP Negeri 2 Kota $S$, yang merupakan salah satu SMP Negeri favorit dan unggulan di Kota S. Kralova (2012) mengungkapkan bahwa tuntutan lebih besar dialami oleh remaja awal yang menjadi siswa di sekolah berkualitas, dibandingkan dengan siswayang bersekolah di sekolah kurang berkualitas. Selain itu, remaja yang telah melalui masa transisi sekolah di tahun pertama, yaitu berada pada kelas VIII, akanmenghadapi tuntutan dari lingkungan yang lebih berat lagi. Kebanyakan remaja belum dipersiapkan untuk menyesuaikan diri menghadapi berbagai tuntutan dan perubahan. Selanjutnya, diperoleh bukti dari hasil penelitian Berg dkk., (2013), bahwa peningkatan jumlah perubahan dalam kehidupan remaja, sangat mempengaruhi penyesuaian diri yang berdampak pada kesejahteraan subjektif remaja.

Berdasarkan data awal yang telah diperoleh peneliti di lokasi penelitian, dapat diketahui bahwa adanya berbagai tuntutan (pribadi, keluarga, sekolah, dan sosial) yang dirasakan oleh siswa kelas VIII di SMP Negeri 2 Kota $S$, mengharuskan siswa untuk mampu menyesuaikan diri dengan baik, karena hal ini berdampak pada kesejahteraan subjektif remaja. Selain itu, permasalahanpermasalahan dalam hubungan sosial yang dialami oleh siswa kelas VIII di SMP Negeri 2 Kota $S$, juga dapat mempengaruhi kesejahteraan subjektif remaja.

Kesejahteraan subjektif remaja juga terkait dengan masalah perkembangan sosial dan emosi yang dialami, yaitu bahwa kecerdasan emosi remaja awal yang masih labil disertai dengan interaksi sosial remaja awal yang semakin luas, sangat mempengaruhi kesehatan dan kesejahteraan subjektif remaja (Ryff dan Singer, 2001). Bar-On (2010) menambahkan bahwa kecerdasan emosi dan interaksi sosial saling terkait yang berfungsi mengarahkan individu pada pencapaian kesejahteraan subjektif.

Kesejahteraan subjektif individu dapat dipengaruhi oleh beberapa faktor, diantaranya: sikap optimisme (Gordeeva dan Osin, 2011; Carr, 2004), kepribadian ekstrovert (Samman, 
2007; Diener, Oishi, dan Lucas, 2003), kecerdasan emosi (Prasetiyo dan Andriani, 2011; Zeidner dan Shemesh, 2010; Gallagher dan Dianne, 2008), spiritualitas (Ekwonye, 2011; Froh, Sefick, dan Emmons, 2008), kontrol diri (Eddington dan Shuman, 2008; Carr, 2004), dandukungan sosial (Ratelle, Simard, dan Guay, 2012; Riddle dan Romans, 2011; Joronen, 2005). Kesejahteraan subjektif individu dapat ditentukan oleh faktor internal dan eksternal individu (Darmayanti, 2012).

Salah satu faktor yang dapat mempengaruhi kesejahteraan subjektif remaja adalah kecerdasan emosi, sebagaimana penelitian Prasetiyo dan Andriani (2011) pada 100 siswa sekolah menengah pertama yang berada pada situasi dan lingkungan baru kecerdasan emosi terkait dengan penyesuaian psikologis dan berperan penting dalam pencapaian kesejahteraan subjektif remaja.

Faktor lain yang dapat mempengaruhi kesejahteraan subjektif adalah dukungan sosial, sebagaimana hasil penelitian Abbey, Abramis, dan Caplan (2005), bahwa dukungan sosial mampu meringankan beban masalah yang dihadapi individu sehingga dapat lebih meningkatkan kesejahteraan subjektif. Berg dkk. (2013) melakukan penelitian pada 846 siswa kelas delapan berusia antara 12 sampai 16 tahun, pada konteks di Afrika Selatan yang mengalami perubahan politik selama tiga dekade terakhir. Hal ini menyebabkan peningkatan masalah emosional dan perilaku di kalangan remaja, karena adanya perubahan struktur masyarakat telah mengikis dukungan sosial dan emosional pada remaja.Masyarakat dinilai semakin lalai untuk memberikan dukungan sosial bagi remaja yang sangat membutuhkan dukungan sosial untuk menghadapi berbagai perubahan lingkungan, termasuk tuntutan internal dan eksternal dari pribadi, keluarga, dan sosial.Penelitian ini menunjukkan bahwa kesejahteraan subjektif remaja sangat terkait dengan dukungan sosial.

Dukungan sosial membantu remaja dalam menyesuaiakan diri, melakukan peran sosial seperti membina hubungan dengan teman, mencapai kemandirian secara emosional dari orangtua dan orang dewasa lainnya, mengurangi tekanan emosional, sehingga dapat merubah suasana hati ke arah yang lebih positif, untuk dapat meningkatkan kesejahteraan subjektif (Demaray dan Malecki, 2002). Selanjutnya, kehadiran dukungan sosial dapat berpengaruh pada perkembangan sosial emosi remaja, serta memberikan kontribusi pada peningkatan kesejahteraan subjektif remaja (Cohen, Gottlieb, dan Underwood, 2000).

Remaja awal berada pada masa transisi dengan berbagai tantangan dan perubahan yang berkaitan dengan perkembangan fisik (pubertas), kognitif, emosi, dan sosial (Coon dan Mitterer, 2012; Mönks dkk., 2004; Brittain dan Hunt, 2003). Selain itu, remaja awal juga mengalami transisi dari sekolah dasar menuju ke sekolah menengah dengan berbagai tuntutan yang lebih kompleks, sehingga sangat mempengaruhi kesehatan mental dan kesejahteraan subjektif (Elias, 2001).

Kesejahteraan subjektif remaja berkaitan dengan masalah perkembangan sosial dan emosi remaja (Ryff dan Singer, 2001). Pergolakan emosi yang terjadi pada remaja awal tidak terlepas dari bermacam pengaruh, seperti lingkungan tempat tinggal, keluarga, sekolah teman-teman, serta aktivitas-aktivitas yang dilakukan dalam kehidupan seharihari. Remaja awal mulai berinteraksi dengan lingkungan sosial yang lebih luas, sehingga dituntut untuk dapat menyesuaikan diri secara efektif (Hartono dan Sunarto, 2013; Marris dan Rae, 2004). Selain itu, Sarlito 
(2006) menjelaskan bahwa gejolak emosi dan berbagai permasalahan remaja, pada umumnya disebabkan oleh adanya konflik peran sosial yang dihadapi remaja.

Hasil penelitian pada 201 siswa menengah di California Selatan, menemukan bahwa kecerdasan emosi yang lebih tinggi mampu melindungi remaja dari kecemasan, depresi, dan masalah berisiko lainnya (Stys dan Brown, 2004). Remaja dengan kecerdasan emosi tinggi akan lebih kompeten dalam berjuang menghadapi tuntutan dan tantangan lingkungan, sehingga individu mudah untuk mencapai tujuan hidup dan kesejahteraan subjektif (Bar-On, 2012).

Penelitian baru-baru ini dilakukan Vesna dan Anna (2013) pada 180 remaja awal berusia 12-15 tahun, yang merupakan siswa kelas VII dan VIII dari suatu sekolah di Dakovo, Kroasia. Bertujuan untuk mempelajari kecerdasan emosi pada remaja awal, hasilnya adalah siswa dengan kecerdasan emosi tinggi, menunjukkan prestasi akademik yang lebih tinggi, mudah menjalin interaksi interpersonal yang relevan untuk fungsi adaptif, mampu mengatur emosi dan suasana hati secara tepat, sehingga dapat mencapai kesejahteraan subjektif.

Remaja awal sangat membutuhkan dukungan sosial pada masa transisi, untuk digunakan dalam mengatasi tekanan dan kecemasan yang ditimbulkan karena adanya berbagai perubahan, perkembangan, serta tuntutan sekolah menengah, sehingga remaja akan mampu menyelesaikan permasalahan yang dihadapi, serta mencapai kesejahteraan subjektif (Kralova, 2012). Dapat dijelaskan bahwa dukungan sosial secara positif berkaitan dengan kesejahteraan subjektif (Cakar, 2013; Basson, 2008; Cohen dkk., 2000), kesehatan fisik dan mental (Cakar, 2013; Abbey dkk., 2005), penyesuaian sosial dan kesuksesan di sekolah (Daly, Shin, Thakral, dan Selders, 2009; Malecki dan Demaray, 2003), serta pencapaian prestasi dan tujuan hidup (Demaray dkk., 2002).

Salah satu fungsi dukungan sosial yaitu dapat meningkatkan kesejahteraan subjektif individu atau disebut sebagai efek moderator (Cohen dkk., 2000; Abbey dkk., 2005; Martin, Mackleod, dan Kannika, 2004). Ditunjukkan oleh hasil penelitian Shashoni dan Slone (2012) pada 417 remaja awal berusia 12-13 tahun, siswa kelas VII dan kelas VIII dari empat sekolah menengah di Israel, bahwa kekuatan karakter positif individu, seperti rasa syukur, kecerdasan emosi, optimisme dan harapan, berdampak pada penyesuaian siswa, serta dipengaruhi oleh interaksi dan dukungan sosial dari jaringan sosial disekitar remaja, yang pada akhirnya dapat meningkatkan kesejahteraan subjektif remaja awal.

Penelitian sebelumnya yang dilakukan oleh Hashim dan Hashimah (2007) pada 209 remaja, yang merupakan siswa dari dua sekolah menengah pertama di Penang, Malaysia, bertujuan untuk menilai stres, coping, dan dukungan sosial sebagai prediktor dari kesejahteraan subjektif siswa. Menunjukkan hasil bahwa jumlah stress yang berhubungan dengan kehidupan sehari-hari sangat mempengaruhi kesejahteraan siswa.

Siswa membutuhkan dukungan sosial dari lingkungan sekitar (seperti: orangtua, guru, dan teman) untuk dapat mengurangi jumlah stres dan meningkatkan kesejahteraan subjektif. Elias (2001) melakukan penelitian pada remaja awal usia 14 tahun, yang bertujuan untuk mengetahui kontribusi kecerdasan emosi pada kesejahteraan subjektif siswa yang dapat ditingkatkan melalui dukungan sosial dari lingkungan rumah dan sekolah 
Hubungan antara variabel independen fokus dalam penelitian ini dapat dilihat pada dengan variabel dependen yang menjadi gambar berikut:

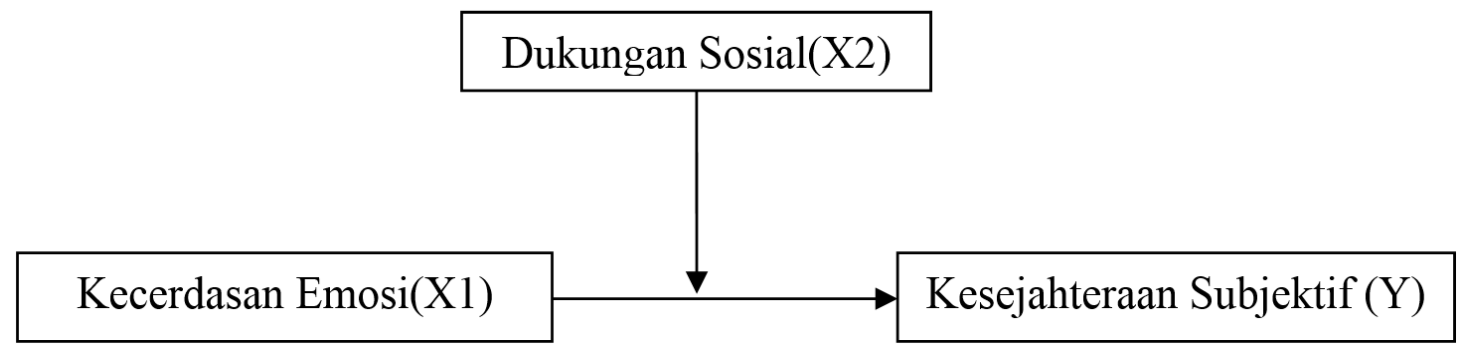

Tujuan penelitian ini adalah untuk mengetahui kesejahteraan subjektif pada remaja awal, dilihat berdasarkan faktor dari dalam individu yaitu kecerdasan emosi dan faktor dari luar individu yaitu dukungan sosial.

\section{METODE PENELITIAN}

Variabel-variabel dalam penelitian ini yaitu, variabel tergantungnya adalah Kesejahteraan subjektif, yang menjadi variabel bebasnya adalah Kecerdasan emosi dan terakhir yang menjadi variabel moderatornya adalah dukungan social

Definisi Operasional Kesejahteraan subjektif adalah penilaian positif individu terhadap diri sendiri mengenai kehidupan yang ditandai dengan perasaan positif yang dimiliki individu lebih besar daripada perasaan negatif, serta tingginya kepuasan hidup individu dalam lingkungan keluarga, teman, dan sekolah. Kecerdasan emosi adalah serangkaian keterampilan yang dimiliki individu dalam mengatur suasana hati untuk dapat merasa optimis dan bahagia, melalui kemampuan memahami diri sendiri dan orang lain, berineraksi dengan orang lain, mengatur dan mengendalikan emosi, serta beradapatasi terhadap berbagai tuntutan dan perubahan hidup. Dukungan sosial adalah persepsi individu mengenai ketersedian bantuan dari individu lain, seperti: orangtua, guru, dan teman, yang dirasakan oleh individu, meskipun tanpa kehadiran fisik individu lain pemberi bantuan, yang dapat digunakan untuk meningkatkan kesejahteraan, membantu menghadapi masalah dan tuntutan hidup, sebagai penyangga stres, sehingga memberikan perasaan nyaman secara fisik dan psikologis.

Penelitian ini dilaksanakan di Sekolah Menengah Pertama (SMP) Negeri 2 Surakarta. Subjek dalam penelitian ini adalah siswa kelas VIII SMP Negeri 2 Surakarta berusia 12-15 tahun, yang merupakan remaja awal.

Skala kesejahteraan subjektif dalam penelitian ini diungkap menggunakan skala kesejahteraan subjektif yang disusun oleh peneliti beserta Naomi, Putri, dan Khairat (2014), berdasarkan dimensi-dimensi kesejahteraan subjektif yang dikemukakan oleh Diener (2009), yaitu dimensi kognitif dan dimensi afektif. Sebagaimana dijelaskan Linley danJoseph(2004), bahwakesejahteraan subjektif merupakan jumlah skor kepuasan hidup dan keseimbangan emosi (emosi positif dikurangi emosi negatif), oleh karena itu, untuk memperoleh skor kesejahteraan subjektif pada penelitian ini, dapat digunakan fungsi atau rumus sebagai berikut:

Kesejahteraan subjektif $=$ Kepuasan hidup + $($ PA-NA $)$ 
Kepuasan hidup : total skor skala dimensi kognitif(kepuasan hidup)

PA

NA

: total skor skala dimensi afektif (afek positif)

: total skor skala dimensi afektif (afek negatif)

Skala kesejahteraan subjektif ini merupakan skala model Likert, terdiri atas pernyataan-pernyataan dengan menggunakan empat pilihan jawaban, yaitu sangat sesuai (SS), sesuai (S), tidak sesuai (TS), dan sangat tidak sesuai (STS). Penilaian aitem favorable bergerak dari skor 4 (sangat sesuai), 3 (sesuai), 2 (tidak sesuai), 1 (sangat tidak sesuai), sedangkan penilaian aitem unfavorable bergerak dari skor 1 (sangat sesuai), 2 (sesuai), 3 (tidak sesuai), 4 (sangat tidak sesuai). Semakin tinggi skor yang diperoleh subjek, semakin tinggi pula kohesivitas kelompok teman sebaya subjek tersebut, dan sebaliknya.

Kecerdasan emosi dalam penelitian ini diungkap menggunakan skala kecerdasan emosiyang disusun sendiri oleh peneliti, berdasarkan aspek-aspek kecerdasan emosiyang dikemukakan Bar-On, Bharwaney, dan MacKinlay (2011), yaitu aspek intrapersonal, aspek interpersonal, aspek adaptasi, aspek manajemen stres, dan aspek pemecahan masalah. Skala kecerdasan emosiini merupakan skala model Likert, terdiri atas pernyataan-pernyataan dengan menggunakan empat pilihan jawaban, yaitu sangat sesuai (SS), sesuai (S), tidak sesuai (TS), dan sangat tidak sesuai (STS). Penilaian aitem favorable bergerak dari skor 4 (sangat sesuai), 3 (sesuai), 2 (tidak sesuai), 1 (sangat tidak sesuai), sedangkan penilaian aitem unfavorable bergerak dari skor 1 (sangat sesuai), 2 (sesuai), 3 (tidak sesuai), 4 (sangat tidak sesuai). Semakin tinggi skor yang diperoleh subjek, semakin tinggi pula kohesivitas kelompok teman sebaya subjek tersebut, dan sebaliknya.

Dukungan sosial dalam penelitian ini diungkap menggunakan skala dukungan sosialyang disusun sendiri oleh peneliti, berdasarkan jenis-jenis dukungan sosial yang dikemukakan oleh Cohen dkk. (2000), yaitu dukungan emosional, dukungan penilaian, dukungan informasi, dan dukungan instrumental. Skala dukungan sosial ini merupakan skala model Likert, terdiri atas pernyataan-pernyataan dengan menggunakan empat pilihan jawaban, yaitu sangat sesuai (SS), sesuai (S), tidak sesuai (TS), dan sangat tidak sesuai (STS). Penilaian aitem favorable bergerak dari skor 4 (sangat sesuai), 3 (sesuai), 2 (tidak sesuai), 1 (sangat tidak sesuai), sedangkan penilaian aitem unfavorable bergerak dari skor 1 (sangat sesuai), 2 (sesuai), 3 (tidak sesuai), 4 (sangat tidak sesuai). Semakin tinggi skor yang diperoleh subjek, maka semakin tinggi pula dukungan sosial subjek tersebut dan sebaliknya.

Uji hipotesis dalam penelitian ini, menggunakan analisis regresi berganda dengan variabel moderator, disebut juga sebagai Moderated Regression Analysis (MRA), merupakan uji interaksi regresi berganda, yang di dalam persamaan regresinya mengandung unsur interaksi, yaitu perkalian antara variabel bebas dengan variabel moderator.

\section{HASIL DAN PEMBAHASAN}

Uji hipotesis dalam penelitian ini menggunakan analisis regresi, sehingga terdapat beberapa uji prasyarat yang harus dipenuhi dalam model regresi, yaitu: uji normalitas, uji linieritas, dan uji multikolinieritas (Priyatno, 2009).

Variabel kesejahteraan subjektif memiliki nilai $\mathrm{K}-\mathrm{SZ}=0,65$ dengan signifikansi $\mathrm{p}$ $=0,200(\mathrm{p}>0,05)$; variabel kecerdasan 
emosi memiliki nilai $\mathrm{K}-\mathrm{SZ}=0,65$ dengan signifikansi $p=0,200(p>0,05)$; serta variabel dukungan sosial memiliki nilai $\mathrm{K}-\mathrm{SZ}=0,60$ dengan signifikansi $\mathrm{p}=0,200$ ( $p>0,05$ ). Nilai signifikansi untuk seluruh variabel $p>0,05$; maka dapat disimpulkan bahwa data pada variabel kesejahteraan subjektif, kecerdasan emosi, dan dukungan sosial berdistribusi normal.

Hasil uji linieritas antara variabel kecerdasan emosi dengan kesejahteraan subjektif diperoleh nilai $\mathrm{F}=118,673$ dengan $\mathrm{p}=0,000(\mathrm{p}<0,05)$; yang berarti bahwa hubungan antara kecerdasan emosi dengan kesejahteraan subjektif adalah linier. Begitu juga dengan hasil uji linieritas antara variabel dukungan sosial dengan kesejahteraan subjektif diperoleh nilai $\mathrm{F}=154,259$ dengan $\mathrm{p}=0,000(\mathrm{p}<0,05)$; menunjukkan hubungan antara dukungan sosial dengan kesejahteraan subjektif adalah linier.

Nilai Variance Inflation Factor (VIF) kedua variabel bebas, yaitu variabel kecerdasan emosi dan dukungan sosial adalah 1,667. Hal ini menunjukkan bahwa antarvariabel independen tidak terdapat persoalan multikolinieritas, karena nilai VIF kurang dari 5.

Penghitungan untuk menguji hipotesis yang diajukan, menggunakan teknik analisis regresi berganda dengan variabel moderator, disebut juga sebagai Moderated Regression Analysis (MRA).Hasil analisis variabel moderator dapat diketahui dengan membandingkan model reggresi 1 , model regresi 2, dan model regresi 3. Hasil uji hipotesis:

Tabel 1. Hasil Uji Hipotesis

\begin{tabular}{ccccc}
\hline Model Regresi & $\mathbf{R}$ & $\mathbf{R}^{2}$ & $\mathbf{F}$ & $\mathbf{P}$ \\
\hline 1 & 0,737 & 0,543 & 136,852 & 0,000 \\
2 & 0,815 & 0,665 & 112,969 & 0,000 \\
3 & 0,817 & 0,667 & 75,478 & 0,000 \\
\hline
\end{tabular}

Hasil analisis menunjukkan bahwa nilai $\mathrm{R}^{2}$ pada model regresi ke-3 lebih tinggi, dengan memasukkan interaksi antara variabel kecerdasan emosi dan variabel dukungan sosial (sebagai variabel moderator), sehingga terbukti bahwa variabel dukungan sosial tepat sebagai variabel moderator yang mampu meningkatkan hubungan antara variabel kecerdasan emosi dengan variabel kesejahteraan subjektif.

Penelitian ini memberikan informasi mengenai hubungan antara kecerdasan emosi, dukungan sosial, dan kesejahteraan subjektif pada remaja awal, menunjukkan bahwa terdapat korelasi positif yang signifikan antara kecerdasan emosi dan dukungan sosial dengan kesejahteraan subjektif. Remaja yang mampu mengenali dan mengelola kecerdasan emosi, serta merasakan dukungan sosial sosial dari lingkungan sekitar, berpengaruh terhadap kesejahteraan subjektif. Selanjutnya, berdasarkan hasil uji hipotesis, dapat diketahui bahwa variabel dukungan sosial sebagai variabel moderator yang berperan menguatkan hubungan antara variabel kecerdasan emosi dengan kesejahteraan subjektif remaja.

Hasil penelitian ini sesuai dengan hasil penelitian sebelumnya oleh Gallagher dan Dianne (2008), menguji nilai prediktif kecerdasan emosi, dukungan sosial, dan efek interaksi keduanya pada kesejahteraan subjektif remaja. Bahwa kecerdasan emosi memberikan pengaruh terhadap kesejahteraan 
subjektif sebesar 44\%, sedangkan dukungan sosial memberikan pengaruh terhadap kesejahteraan subjektif sebesar 50\%.

Subjek dalam penelitian ini sebanyak 117 siswa dengan rentang usia antara 12-15 tahun. Usia rata-rata subjek adalah 13,74 tahun dan mayoritas subjek berusia 14 tahun, yaitu sejumlah 87 sisiwa $(74,36 \%)$. Selain itu, dapat diketahui bahwa sebagian besar subjek, berjumlah 77 siswa (65.81\%) memiliki tingkat kesejahteraan subjektif tinggi. Hal ini konsisten dengan beberapa penelitian sebelumnya yang menunjukkan bahwa mayoritas remaja awal mengalami kesejahteraan subjektif yang tinggi (Basson, 2008).

Berdasarkan hasil analisis data, dapat diketahui bahwa kecerdasan emosi dan dukungan sosial mempengaruhi kesejahteraan subjektif remaja. Sebagaimana penjelasan Eddington dan Shuman (2008) bahwa kesejahteraan subjektif dipengaruhi oleh faktor internal (misalnyai:kepribadian, temperamen, kecerdasan emosi, optimisme, dan harga diri), serta faktor eksternal (misalnya: status ekonomi, dukungan sosial, pendidikan, budaya, dan hubungan sosial). Oleh karena itu, dapat dikatakan bahwa kesejahteraan subjektif remaja dalam penelitian ini dipengaruhi oleh kecerdasan emosi (faktor internal) dan dukungan sosial (faktor eksternal).

\section{SIMPULAN}

Kesejahteraan subjektif adalah penilaian positif individu terhadap diri sendiri mengenai kehidupan yang ditandai dengan perasaan positif yang dimiliki individu lebih besar daripada perasaan negatif, serta tingginya kepuasan hidup individu dalam lingkungan keluarga, teman, dan sekolah.

Kesejahteraan subjektifdapat dipengaruhi oleh beberapa faktor, diantaranya adalah faktor internal (seperti: kecerdasan emosi, control diri, spiritualitas, optimisme, dan harga diri), serta faktor eksternal (seperti: dukungan sosial, budaya, dan hubungan sosial). Kesejahteraan subjektif remaja awal dalam penelitian ini dipengaruhi oleh kecerdasan emosi (faktor internal) dan dukungan sosial (faktor eksternal) yang tidak dapat berdiri sendiri, saling mempengaruhi, berinteraksi dan berproses, sehingga dapat menghasilkan serta mencapai kesejahteraan subjektif yang tinggi (positif).

Berdasarkan hasil analisis data, dapat diketahui bahwa kecerdasan emosi, dukungan sosial, dan kesejahteraan subjektif memiliki hubungan positif yang signifikan. Remaja yang memiliki kecerdasan emosi tinggi serta merasakan dukungan sosial tinggi, juga memiliki kesejahteraan subjektif yang tinggi.Hasil uji hipotesis menjelaskan bahwa variabel dukungan sosial merupakan variabel moderator yang berperan menguatkan hubungan variabel kecerdasan emosi dengan kesejahteraan subjektif.

Kesejateraan subjektif merupakan salah satu topik menarik yang dapat ditemukan pada diri individu, termasuk juga pada remaja awal. Bahwa dalam pencapaian kesejahteraan subjektif yang tinggi, tidak hanya ditentukan oleh kondisi bawaan individu (faktor internal), tetapi juga oleh situasi lingkungan yang dihadapi (faktor eksternal). Oleh karena itu, untuk dapat memahami kesejahteraan subjektif individu, perlu untuk memperhatikan keadaan individu itu sendiri serta situasi lingkungan di sekitar individu.

Subjek penelitian ini adalah remaja awal berusia 12-15 tahun yang merupakan siswa sekolah menengah pertama. Tujuan penelitian ini untuk mengetahui tingkat kesejahteraan subjektif pada remaja awal. Ketika individu dapat mencapai kesejahteraan subjektif yang tinggi pada masa remaja awal, akan 
menjadi pijakan kuat dan sehat bagi tahap perkembangan selanjutnya.

Akan tetapi, subjek penelitian ini, yang merupakan remaja awal, bahwa karakteristik perkembangan yang paling menonjol pada masa remaja awal cenderung lebih memfokuskan diri pada perkembangan fisik dan belum begitu memperhatikan kesejahteraan subjektif. Hal inilah yang menjadikan salah satu keterbatasan dari penelitian ini.
Penelitian selanjutnya dapat memperluas karakteristik perkembangan dari subjek penelitian, yaitu pada individu dengan tahap perkembangan yang lebih tinggi, sehingga kesejahteraan subjektif dapat dipahami secara lebih dominan oleh subjek penelitian dengan dengan tahap perkembangan yang lebih tinggi, dibandingkan dengan subjek penelitian pada remaja awal.

\section{DAFTAR PUSTAKA}

Abbey, A., Abramis D.J., \& Caplan R.D. (2005). Effect of differents sources of social support and social conflict on subjective well-being. Basic and Applied Social Psychology, 6, 2, 111-129.

Armstrong, T. (2011).The best school: Mendidik siswa menjadi insan cendikia seutuhnya (Penerjemah: Lovely dan Mursid Widjanarko). Bandung: P.T. Mizan Pustaka.

Bar-On, R. (2010). Emotional intelligence: An integral part of positive psychology. South African Journal of Psychology, 40, 1, 54-62.

Bar-On, R, (2012).The impact of emotional intelligence on health and well-being: Emotional intelligencenew persceptions and applications. Croatia: InTech Europe.

Basson, N. (2008). The influence of psychosonal factors on the subjective well-being of adolescents. (Dissertation doctoral unpublished).Department of Psychology, University of the Free State, Bloemfontein.

Berg, H.V., George, A.A., Edwin, D.P., Anja, B., Basson, N., Marisa, DV.,\& Solomon, M. (2013). The pivotal role of social support in the well-being of adolescents.Well-Being Research.doi: 10.1007/978-94-007-6368-5-15.

Brittain, C., \& Hunt, D.E. (2003).Child and adolescent development. New York: Oxford University Press.

Cakar F.S. (2013). Behavior problems and social support which adolescent perceived from the different sources. International Education Research, 1, 2, 50-64.

Carr, A. (2004). Positive psychology: The science of happiness and human strengths. New York: Brunner-Routledge

Cohen, S., Gottlieb, B., \& Underwood, L. (2000).Social support measurement and intervention: A guide for health and social scientists. New York: Oxford University Press.

Coon, D., \& Mitterer, J.O. (2012).Psychology: A journey (5th Edition). Belmont: Wadsworth Cencage Learning. 
Daly, B.P., Shin, R.Q., Thakral, C., Selders, M., \& Vera, E. (2009). School engagement among urban adolescents of color: Does perception of social support and neighbourhood safety really master? Journal Youth Adolescents, 38, 63-74. doi: 10.1007/5 10964-008-9294-7.

Darmayanti, N. (2012). Model kesejahteraan subjektif remaja.(Disertasi doktor tidak dipublikasikan).Yogyakarta: Universitas Gadjah Mada.

Demaray, M.K., \& Malecki, C. P. (2002). Critical levels of perceived social support associated with students adjustment. School Psychology Quarterly, 17, 213-241.

Diener, E., Oishi, S., \& Lucas, R.E. (2003). Personality, culture, and subjective well-being: emotional \& longitudinal evaluation of live. Annual Review Psychology, 54, 403-425. doi: 10.11461 annurev.pych. sn. 10601.1445056.

Diener, E. (2008). The science of subjective well-being. New York: Guilford Publications.

Diener, E. (2009). The science of well-being. Champaign: Springer.

Diener, E., \& Biswas, R. (2011).Positive psychology as social change.New York: Springer.

Eddington, N. \& Shuman R. (2008).Subjective well-being. Florida: Continuing Psychology Education Inc.

Eid, M., \& Larsen, R.J. (2008).The science of subjective well-being. New York: The Guilford Press.

Ekwonye, A.U. (2011). Adolescent, social support, religiosity and spirituality.(Dissertation doctoral unpublished). New Jersey:Seton Hall University.

Elias, M.J. (2001). Easing transitions with social emotional learning. Principle Leaderships, hal.20-25.

Froh, J.J., Sefick, W.J., \& Emmons, R .A. (2008). Early adolescents: An experimental study of subjective well-being. Journal of School Psychology, 46, 213-233.

Gallagher, E.N., \& Dianne A. (2008). Social support and emotional intelligence as predictors of subjective well-being.Personality and Individual Differences, 44, 1551-1561.

Gordeeva, T.O., \& Osin, E.N. (2011).Optimistic as a predictor of subjective well-being.The Human Pursuit of Well-Being, 14, 159-174. doi: 10.1007/978-94-067-1375-8-14.

Hashim, M. \& Hashimah,I. (2007). Stress, coping, social supports, and subjective well-being in the adolescent years.Kajian Malaysia, 1, 97-115.

Joronen, K. (2005). Adolescents subjective well-being in their social contexts.(Dissertation doctoral unpublished).University of Tampere, Finnish.

Kralova, E. (2012). Importance of supporting social and emotional well-being of pupils in their transition to middle school.University Review, 6, 1, 45-53.

Linley, P.A., \& Joseph, S. (2004). Positive psychology in practice. New Jersey: John Willey $\&$ Sons, Inc. 
Malecki, C.K., \& Demaray M.K. (2003). What type of support do they need? investigating student adjustment as related to emotional, informational, appraisal, and instrumental support. School Psychology Quarterly, 18, 3, 231-252.

Marris, B., \& Rae, T. (2004). Social and emotional literacy programmes and resources. Amazon: SAGE Publications.

Martin, L., Mackleod, K., \& Kannika, N. (2004). Assessing the main and moderating effects of social support in relation to stressfull live events and psychiatric symptoms. Final Paper of Proposal Research, 1-37.

Naomi, O., Putri, D.R., \& Khairat, M. (2014).Pengukuran skala kesejahteraan subjektif pada remaja awal.Laporan Penelitian. Universitas Gadjah Mada Yogyakarta.

Prasetiyo, A., \& Andriani, I. (2011).Kecerdasan emosi dan subjective well-being pada siswa. Jurnal Psikologi Universitas Gunadharma, 4, 13-19.

Ratelle, C.F., Simard, K., \& Guay, F. (2012). Students' subjective well-being: the role of social support. Journal of Happiness Study, hal.1-18.

Riddle, G.S., \& Romans, J.S.C. (2011). Resilience among urban american indian adolescents: exploration into the role of culture, subjective well-being, and social support. American Indian and Alaska Native Mental Health Reaserch, 19, 2, 1-19.

Ryff, C.D., \& Singer, B.H. (2001).Emotion, social relationships, and health. New York: Oxford University Press.

Samman, E. (2007). Psychological and subjective well-being: A proposal for internationally comparable indicators. New York: Oxford University Press.

Santrock, J.W. (2007). Life span development (13 th edition). New York: McGraw-Hill.

Sarlito, W.S. (2006). Psikologi remaja. Jakarta: P.T. Raja Grafindo Persada.

Stys, Y., \& Brown S,L. (2004). A review of the emotional intelligence literature and implications for corrections.Research Report, page 1-76.

Vesna, B., \& Anna, (B. 2013). Emotional intelligence in early adolescence.International Journal of Humanities and Social Science Invention, 2, 5, 54-62.

Zeidner, M., \& Shemesh, D.O. (2010). Emotional intelligence and subjective well-being revisited. Personality and Individual Differences, 48, 431-435.

Zulkifli. 2006. Psikologi perkembangan. Bandung: P.T. Remaja Rosdakarya. 